\title{
Classification and Risk-Mapping of River Water Quality in Surabaya with Semantic Visualitzation
}

\author{
Taufan Radias Miko, Tri Harsono, Aliridho Barakbah \\ Electronic Engineering Polytechnic Institute of Surabaya \\ Jl. Raya ITS Politeknik Elektronika, Kampus ITS Sukolilo, Surabaya \\ (031) 5947280 \\ E-mail: taufan0404@gmail.com, \{trison,ridho\}@pens.ac.id
}

Received May 18, 2019; Revised August 23, 2019; Accepted October 22, 2019

\begin{abstract}
River water pollution is one of the environmental problems that occur in Surabaya. The amount of industrial waste and household waste makes Surabaya River water easily polluted every day, besides that there are also many people who are not aware about the quality of river water in Surabaya. In this paper, we present a new system to classify water quality of river in surabaya. The system involve a semantic visualization of risk-mapping for the river, so that the people of Surabaya are easier to get information about the quality of Surabaya River water. In this paper, we measured the water quality of Surabaya River using Horiba sensor measuring instruments using 5 parameters, namely temperature, PH, DO, Turbidity, TDS. These five parameters are input variables for calculating water quality with the methods applied in this research. We use the Storet Method to determine the quality of Surabaya River water. The results of the Storet Method explained that there were $0.03 \%$ of the data on lightly polluted water quality and there were $37.41 \%$ of the data being moderately polluted and there were $59.29 \%$ of the data heavily polluted. The results of the calculation using the Storet method concluded that the condition of Surabaya River water quality was not good. We also apply the rule of the Storet Method to the Neural Network by using Surabaya River water quality data as learning data and gave performance $70.02 \%$ accuracy.
\end{abstract}

Keywords: Classification, Neural Network, Storet Method, Water Quality, Semantic Visualization

\section{INTRODUCTION}

Water is a natural resource that is needed by everyone, even by all living things. One source of water that is widely used to meet the living needs of humans and other living things is the river. Rivers are ecosystems that are very important for humans. The river has a function as raw material for processing clean water, transportation, irrigation, fisheries, and others [1]. 
River water coming out of springs usually has very good quality, but in the process of drainage the water will receive various kinds of pollutants from human activities such as industrial activities, households, etc. that cause river water pollution.

River water pollution is a change in the state of river water caused by human activities. This change resulted in a decrease in water quality to a dangerous level so that water could not be used according to its designation [2]. River water pollution is one of the environmental problems that occur in Surabaya. Surabaya River water pollution is caused by domestic waste and industrial waste [3]. The Surabaya city government recognizes that the quality of Surabaya River water is below the specified quality standard. According to the head of the Environment Agency (BLH) the highest pollution is caused by pollution of household waste [4].

In the Surabaya River Pollution, the Control Action Plan Study obtained data that the Surabaya River accommodates industrial pollution loads of 75.48 tons per day. Whereas the maximum potable raw water for waste disposal must be 30 tons per day in all Surabaya River flows. The number of E-coli bacteria in Surabaya River reaches 64,000 bacterial cells / $100 \mathrm{ml}$, whereas the feasibility of raw water must be less than 1000 bacterial cells / $100 \mathrm{ml}$ of water samples (PP No.82 of 2001). With the problems mentioned above, it shows that the PDAM's water raw material is getting worse in Surabaya, so that more chemicals are used for processing, so if consumed for drinking water or cooking is not very good, especially in our body's health problems.

In the current water classification system using the storet method which is calculated manually so it takes a long time and the results of the storet method are displayed in the form of numbers, therefore in this study we propose a new approach using the Storet Method to determine water quality and Neural Network Classification. used to apply the rules of the Storet Method so that in the future we will be easier and faster in the classification of water quality.

The results of the classification will be mapped in the form of semantic visualization aimed at making it easier for related communities, especially the people of Surabaya to see the condition of the Surabaya river water quality.

\section{RELATED WORKS}

In previous research on river water quality that has been carried out by several researchers using different parameters or methods, namely Ayu Ratri Wijayaning Hakim and Yulinah Trihadiningrum conducted research on Brantas River water quality [5]. Parameters used are chemistry, physics and biology. The chemical parameters used were BOD, DO, Phosphate, ammonium while the physical parameters used were $\mathrm{PH}$, Temperature, Turbidity and biological parameters using the physical state of the water. 
Physical and chemical parameters were measured using the Lisec Score Method while the biological parameters used the Bioassesment Method. The purpose of this study is to measure the physical, chemical and biological qualities of water so that they can find out the correlation between physical, chemical and biological qualities.

Fawaz Al-Badaii, Mohammad Shuhaimi-Othman and Muhd Barzani Gasim conducted a study of the water quality of the Semenyih Selangor Malaysia River [6]. In this paper to measure water quality using several parameters including Temperature, $\mathrm{PH}$, Conductivity, TDS, SO4, DO, TH, Turbidity, BOD, NH3-N, TSS, COD, OG, NO3 and measurement methods using the Standard Method. The results showed that Temperature, PH, conductivity, TDS, SO4, and TH were classified as class I. While DO, Turbidity, and BOD were categorized under class II, and NH3-N, TSS, COD, and OG were categorized as class III. NO3 is classified in class IV, while PO4 and FC are categorized as class $\mathrm{V}$ and exceed the allowable threshold

Sri Rahmawati F, M. Isa Irawan and Nieke Karnaningroem conducted a study on the pattern of pollutant distribution in Surabaya River using the Kohonen network [7]. Kali Surabaya is the place for taking water samples and the parameters used are 4 parameters, namely BOD, COD, DO and TSS. In this paper using several methods including data cleaning, artificial neural networks and kohonen networks. Data cleaners are used to complete incomplete data and refine noise, while the kohonen method is a method derived from the approach of the artificial neural network method. The cluster results on Surabaya River water quality using the kohonen network obtained a minimum Davies Bouldin Index value of 53,742 with a learning rate of 0.4 and the number of iterations 672 . The results of the Kohonen Network training provided an overview of water pollution in Surabaya River.

Muh Faisal Dinniy, Ali Ridho Barakhbah, Entin Martiana Kusumaningtyas conducted a study on the classification of water quality measurements using Neural Network by strengthening programming for weighting optimization [8]. In this paper involved four parameters for measuring water quality, namely BOD, COD, PH, Suspended Solid and using UCI (University of California Irvine) data. The method used to process data using the Backpropagation Neural Network Classification Method. The experiment In this paper was used to examine and analyze the application of the proposed algorithm. From the experiments, it was shown that the Neural Network improved with reinforcement programming, while the weighting mechanism outperformed reinforcement programming, while SSE, the number of iterations and computational time was less than Backpropagation Neural Network in heavy updates.

MA Huiqun and LIU Ling conducted a study on water quality by using Artificial Neural Network [9]. The research sample was conducted at Dongchang Lake in Liaocheng City, China. The method used to process data using Artificial Neural Network and Fuzzy. Both of these methods are very suitable to use because Artificial Neural Network is often used for 
environmental modeling and its capabilities are accurately very complex, but for non-linear processes it is relatively poorly understood so that nonlinearity is very suitable to be assessed by fuzzy. In this paper using 3 parameters, namely BOD, TN, TP. When training data is carried out using 500 epoch the results for the error rate are stable, which is an error rate of 0.568307 or very low.

Table 1. Comparison of Previous Studies With Proposed Research

\begin{tabular}{|c|c|c|c|c|}
\hline \multicolumn{5}{|c|}{ Previous Research } \\
\hline Name & Title & Parameter & Method & $\begin{array}{l}\text { Data } \\
\text { Collection } \\
\text { Place }\end{array}$ \\
\hline $\begin{array}{l}\text { Ayu Ratri } \\
\text { Wijayaning } \\
\text { Hakim dan } \\
\text { Yulinah } \\
\text { Trihadiningr } \\
\text { um }\end{array}$ & $\begin{array}{l}\text { Brantas River Water } \\
\text { Quality Based on } \\
\text { Macroinvertebrates }\end{array}$ & $\begin{array}{l}\text { BOD, DO, } \\
\text { Phosphate, } \\
\text { Ammonium, } \\
\text { PH, } \\
\text { Temperature, } \\
\text { Turbidity }\end{array}$ & $\begin{array}{l}\text { Lisec Score, } \\
\text { Bioassesment }\end{array}$ & $\begin{array}{l}\text { Brantas } \\
\text { River }\end{array}$ \\
\hline $\begin{array}{l}\text { Fawaz Al- } \\
\text { Badaii, } \\
\text { Mohammad } \\
\text { Shuhaimi- } \\
\text { Othman dan } \\
\text { Muhd } \\
\text { Barzani } \\
\text { Gasim }\end{array}$ & $\begin{array}{l}\text { Water Quality } \\
\text { Measurement for } \\
\text { Semenyih River } \\
\text { Selangor Malaysia }\end{array}$ & $\begin{array}{l}\text { Temperature, } \\
\text { PH, } \\
\text { Conductivity, } \\
\text { TDS, SO4, DO, } \\
\text { TH, Turbidity, } \\
\text { BOD, NH3-N, } \\
\text { TSS, COD, OG, } \\
\text { NO3 }\end{array}$ & $\begin{array}{l}\text { Standard } \\
\text { Method }\end{array}$ & $\begin{array}{l}\text { Semenyih } \\
\text { River } \\
\text { Selangor } \\
\text { Malaysia }\end{array}$ \\
\hline $\begin{array}{l}\text { Sri } \\
\text { Rahmawati } \\
\text { F, M. Isa } \\
\text { Irawan dan } \\
\text { Nieke } \\
\text { Karnaningro } \\
\text { em }\end{array}$ & $\begin{array}{l}\text { The Distribution Of } \\
\text { Pollutants In The } \\
\text { Surabaya River Using } \\
\text { The Kohonen Network }\end{array}$ & $\begin{array}{l}\text { BOD, COD, DO } \\
\text { dan TSS }\end{array}$ & $\begin{array}{l}\text { Data } \\
\text { normalization, } \\
\text { neural network, } \\
\text { kohonen } \\
\text { network }\end{array}$ & $\begin{array}{l}\text { Surabaya } \\
\text { River }\end{array}$ \\
\hline $\begin{array}{l}\text { Muh Faisal } \\
\text { Dinniy, Ali } \\
\text { Ridho } \\
\text { Barakhbah, } \\
\text { Entin } \\
\text { Martiana } \\
\text { Kusumaning } \\
\text { tyas }\end{array}$ & $\begin{array}{l}\text { Classification Of Water } \\
\text { Quality Measurements } \\
\text { Using Neural } \\
\text { Networks With } \\
\text { Programming } \\
\text { Reinforcement For } \\
\text { Weighting } \\
\text { Optimization }\end{array}$ & $\begin{array}{l}\text { BOD, COD, PH, } \\
\text { Suspended Solid }\end{array}$ & Neural Network & $\begin{array}{l}\text { data UCI } \\
\text { (University } \\
\text { of } \\
\text { California } \\
\text { Irvine) }\end{array}$ \\
\hline $\begin{array}{l}\text { MA Huiqun } \\
\text { dan LIU Ling }\end{array}$ & $\begin{array}{l}\text { Water Quality By } \\
\text { Using An Artificial } \\
\text { Neural Network }\end{array}$ & BOD, TN, TP & $\begin{array}{l}\text { Artificial Neural } \\
\text { Network and } \\
\text { Fuzzy }\end{array}$ & $\begin{array}{l}\text { Lake } \\
\text { Dongchang }\end{array}$ \\
\hline \multicolumn{5}{|c|}{ Proposed Research } \\
\hline $\begin{array}{l}\text { Taufan } \\
\text { Radias Miko, } \\
\text { Tri Harsono, } \\
\text { Aliridho } \\
\text { Barakbah }\end{array}$ & $\begin{array}{l}\text { classification and } \\
\text { mapping of river } \\
\text { water quality in } \\
\text { Surabaya with } \\
\text { semantic visualization }\end{array}$ & $\begin{array}{l}\text { Temperature, } \\
\text { Ph, Turbidity, } \\
\text { DO, and TDS }\end{array}$ & $\begin{array}{l}\text { Stored methods, } \\
\text { Normalization, } \\
\text { Neural } \\
\text { Network, }\end{array}$ & $\begin{array}{l}\text { Surabaya } \\
\text { River }\end{array}$ \\
\hline
\end{tabular}




\section{ORIGINALITY}

In this paper we propose a new system to the quality of Surabaya River water using the Storet Method and Neural Network. The storet method is used to determine river water quality. River water quality is divided into 4 , namely quality standards, mild pollution, moderate pollution and heavy pollution. The principle of the Storet Method is to compare the water parameter value data with the water quality standard value. If the value of the water $<=$ quality standard parameter is given a score of 0 , if the value of the water parameter> from the quality standard then we look for the maximum, minimum and average values, then compare the three values with the water quality standard and give the score accordingly water quality regulations, After that the score for each parameter is added up. If the total score is 0 then it includes the standard quality water class, if the total score is -1 to -10 then it includes the light polluted water class, if the score is -11 to 30 then it includes the moderate polluted water class, if the number is $>-30$ then it includes a class of heavily polluted water. In this paper the Neural Network is used to apply the rule of the existing Storet Method. The learning data uses the results of sampling Surabaya River water quality and the target data using the results of the Storet Method calculation. The target data consists of three numbers, namely the number $0,1,2$. Number $0=$ moderate pollution, number 1 = heavy pollution, and number $2=$ mild pollution. In this paper we use the structure of the Neural Network as follows: miu 0.5, epoch 10000, hidden unit 25.20. For testing data we use Leave One Out (LOO) so that it gets an accuracy value of $70.02 \%$.

\section{SYSTEM DESIGN}

Here we describe our proposed system. In this paper, we have 5 stages of our proposed system, which are (1) data collection, (2) data preprocessing, (3) data classification, (4) risk-mapping and (5) visualization of Surabaya River water. The system design diagram in this study can be seen in Figure 1.

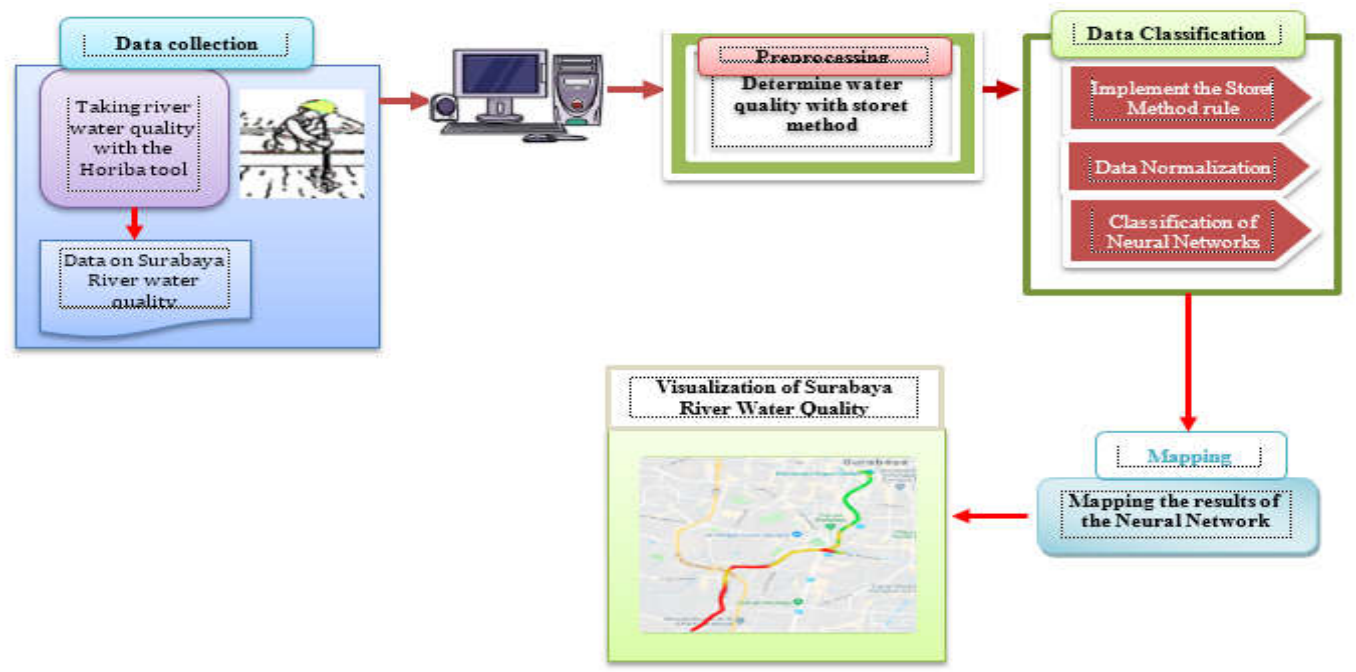

Figure 1. System Design 


\subsection{Data collection}

In this study we collected data by taking samples of the Surabaya River water quality. We took samples of the Surabaya River water quality using a Horiba U52 sensor. In Horiba sensors there are 12 sensors including Temperature, Turbidity, Dissolved oxygen (DO), $\mathrm{Ph}, \mathrm{Ph}(\mathrm{mV})$, conductivity, oxidation-reduction potential (ORP), water depth, TDS (Total Dissolved Solids), Salinity, the specific gravity of seawater, but in this study we use 5 sensors as a classification parameter and mapping of river water quality in Surabaya. The five parameters are Temperature, Ph, Turbidity, DO, and TDS. We do the sampling in May, September, October. The sample of river water quality in Surabaya that we successfully collected amounted to 456 data from 64 points. From the 456 data we take, the average value of the Temperature and $\mathrm{Ph}$ parameters are not in accordance with the water quality standard value, while the DO, Turbidity, and TDS parameter values are in accordance with the water quality standard value. Data from the measurement of samples with this horiba tool in the form of unsupervised data is data that does not have a label. Table 2 Partial data - data results from measurements with Horiba measuring devices.

Table 2. Partial Data on Water Sampling Results with Horiba

\begin{tabular}{|c|c|c|c|c|}
\hline \multirow{2}{*}{ Temperature } & PH & turbidity & DO & TDS \\
\hline 29.43 & 9.01 & 50 & 8.17 & 0.084 \\
\hline 29.47 & 9.95 & 50.3 & 3.69 & 0.087 \\
\hline 29.86 & 9.49 & 31.4 & 3.5 & 0.089 \\
\hline 29.42 & 9.57 & 49.1 & 4.8 & 0.087 \\
\hline 29.86 & 9.42 & 50.1 & 2.79 & 0.088 \\
\hline 29.74 & 10.1 & 48.2 & 7.93 & 0.088 \\
\hline 29.89 & 9.5 & 43.7 & 2.94 & 0.09 \\
\hline 29.48 & 10.05 & 34.6 & 1.33 & 0.101 \\
\hline 29.95 & 9.53 & 50.2 & 3.59 & 0.112 \\
\hline 30.1 & 9.52 & 5 & 3.2 & 0.089 \\
\hline 29.42 & 9.12 & 48 & 5.55 & 0.084 \\
\hline 29.43 & 10.79 & 50.2 & 8.22 & 0.087 \\
\hline 29.82 & 9.45 & 50 & 4 & 0.089 \\
\hline 30.15 & 9.47 & 50.1 & 2.05 & 0.096 \\
\hline 30.11 & 9.43 & 43.1 & 2.11 & 0.088 \\
\hline 30.17 & 9.43 & 40.8 & 2.77 & 0.087 \\
\hline 30.12 & 9.37 & 41.5 & 1.77 & 0.088 \\
\hline & & & & \\
\hline
\end{tabular}




\subsection{Preprocessing data}

In this stage, storet method was used to get river water quality. It is divided into 3, namely the quality of lightly polluted water, medium polluted, heavily polluted. Technically, the stored method comparing between water quality data and water quality standards that are adjusted to their designation to determine water quality status. Steps of determination of water quality status using the Storet Method are: first, collecting data periodically so that we having it from time to time, then looking for maximum, minimum and average values for each parameter. Those values are compared with the quality standard values that correspond to the water class. Table 3 . is the status of the quality standard parameters used in this study.

Table 3. Standard Status of Water Parameter Quality

\begin{tabular}{|c|c|c|c|c|c|}
\hline Parameter & Temperature & Ph & TDS & DO & Turbidity \\
\hline $\begin{array}{c}\text { Quality } \\
\text { standards }\end{array}$ & $+/-3\left(28^{0} \mathrm{C}\right)$ & $6-8,5$ & - & $>=3$ & 25 NTU \\
\hline $\begin{array}{c}\text { Type of } \\
\text { liquid }\end{array}$ & physics & chemistry & physics & chemistry & physics \\
\hline
\end{tabular}

If the measurement results meet the water quality standard (the measurement results $<=$ quality standard) then given a score of 0 but if the measurement results do not meet the water quality standard (measurement results $>$ quality standards), then given a score according to Table 4 .

Table 4. Determination of The Measured Water Quality Score

\begin{tabular}{|c|l|c|c|c|}
\hline \multirow{2}{*}{$\begin{array}{c}\text { Number of } \\
\text { examples }\end{array}$} & value & \multicolumn{3}{|c|}{ parameter } \\
\cline { 3 - 5 } & & physics & chemistry & biology \\
\hline \multirow{2}{*}{$<10$} & Maximum & -1 & -2 & -3 \\
& Minimum & -1 & -2 & -3 \\
\hline$>10$ & Average & -3 & -6 & -9 \\
\hline & Maximum & -2 & -4 & -6 \\
& Minimum & -2 & -4 & -6 \\
& Average & -6 & -12 & \\
\hline
\end{tabular}

Calculation of scores on each parameter is based on table 4 to produce minimum, maximum, and average values. After that, the results of the calculation are converted to their respective scores so that the minimum, maximum, and average scores are obtained. Based on the Decision State 
Minister Of Environment Number: 115 of 2003 About Guidelines For Determining The Quality Of Water Status, the results of the scores for each parameter are summed (the sum of the minimum, maximum, and average scores). Then, the sum of the scores on each parameter (temperature parameters, $\mathrm{PH}$, trubidity, DO, and TDS) is summed to produce a total score. Based on "US-EPA (Environmental Protection Agency)", the total score of the water quality is classified into four types of classes, namely:

(1) Class A: very good, score $=0$ (meets quality standards)

(2) Class B: good, score $=-1$ to -10 (mild pollution)

(3) Class C: moderate, score $=-11$ to -30 (moderate pollution)

(4) Class D: bad, score $>=-31$ (severe pollution)

\subsection{Data Classification}

Classification is an absorption word from the Dutch language, namely classificate [10]. Classification is a method of grouping based on the size of proximity (similarity) of an existing sample characteristic, one of which uses the ecluidean distance formula and the data must be labeled. Classification is different from the group, if the group means the same group of conditions, otherwise it is definitely not the group [11][23].

In this study, we used the rule from the Storet Method that we applied to the classification method of neural network, in which the target data using the output of the calculation of the Storet Method. In this data classification we use five parameters namely temperature, $\mathrm{pH}$, DO, TDS, turbidity. We classified these five parameters into four labels, namely standard quality water, mild polluted water, moderate polluted water, and heavy polluted water. Data is processed using the data normalization method before the data classification process is carried out.

\subsubsection{Data Normalization}

Normalization is a process to set attribute values from data in which the value can enter a certain range and minimize data redundancy so that the database can work optimally [12]. In this study, we normalized the data using the minmax normalization method. Minmax normalization is a way to normalize a data with a maximum range and a new minimum that we have set, which is usually called the normalization interpolation. The minmax normalization formula was used the following formula :

newdata $=($ data-min $) *($ newmax-newmin $) /(\max -\min )+$ newmin

where:

newdata $=$ normalization data

$\min =$ minimum value of data per column

$\max =$ the maximum value of data per column

newmin $=$ is the minimum limit we give

newmax $=$ is the maximum limit we give

In our research using the range for MinMax is $[0,1]$. 


\subsubsection{Neural Network}

Neural Networks have many names including Artificial Neural Networks (ANN), Artificial Neural Networks (ANN), Simulated Neural Networks (SNN), Neural Networks (NN) [13]. Neural Network is a network system whose network structure is like the human brain and is a category of Soft Computing science that adopts the capabilities of the human brain which is usually implemented using electronic components [14] [15] [16]. One of the most popular Neural Network classification methods is the Backpropagation algorithm. Backpropagation algorithm consists of 2 main parts of the training process, namely Forward Pas and Backward Pas. For more details can be seen in Figure 2 below:

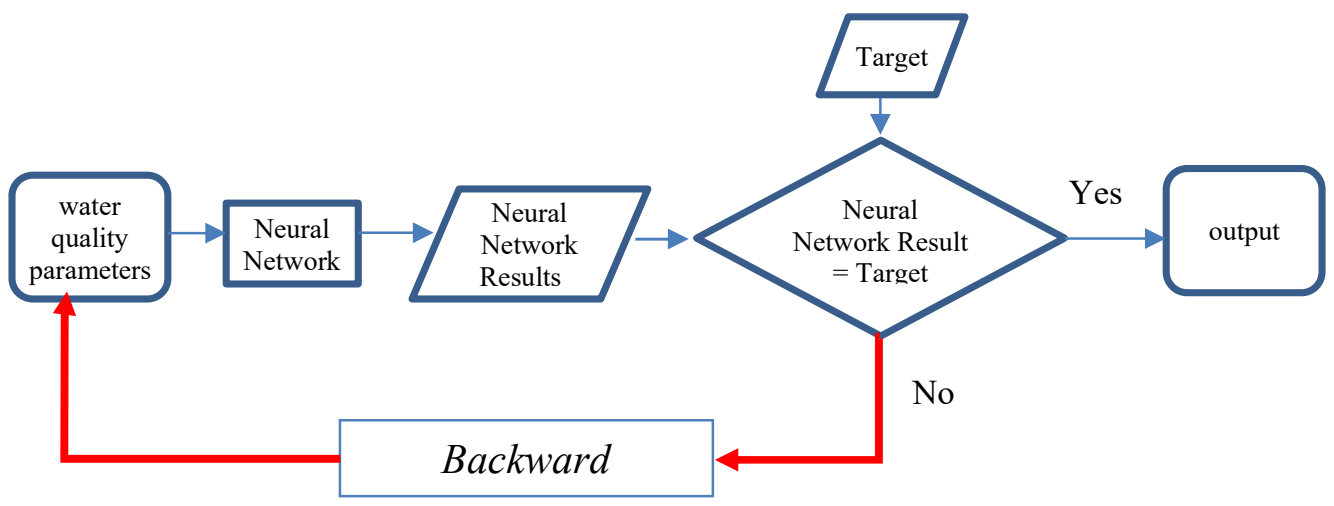

Figure 2. Neural Network Training

In Figure 2, the blue arrow describes the Forward Pass and the red arrow describing the Backward Pass. In Supervised Learning training data consists of inputs and targets. At Forward Pass, the input will be "propagated" towards the output layer and the output prediction results will be compared with the target using a function commonly called Loss Function. Loss Function functions to measure how well the performance of our Neural Network is in predicting targets. There are several types of Loss Functions, but what is often used is Squared Error. In this study, we used the Backpropagation Neural Network Algorithm Method by using two hidden units.

\subsection{Mapping of water quality classification results}

As stated in the previous section, this study presents the results of the classification of river water quality in Surabaya. Mapping of these results is based on maps so that the results of this mapping can provide information to the relevant community about river water quality around Surabaya. Webbased visualization is built on this system so that the information presented about river water quality becomes clearer and communicative. 


\subsection{Semantic Visualization}

Visualization is engineering in the form of images or animations in which an information is displayed so that everyone can easily understand the information conveyed [17]. Besides that Visualization is defined as a method to represent a data or problem into a graphic format or an image form that is easy to understand [18].

The word semantics comes from the Greek, Sema (noun) which means a sign or symbol, and the verb Samaino which can be referred to as marking or symbolizing. Semantic is a branch of linguistics that studies the meaning contained in language[19][20].

Semantic visualization is to present objects or actual conditions in the form of symbols, images or animations which contain meaning to display information [21] [22]. In this study, we present the Surabaya river water quality in the form of a map in which there is a symbol or symbol of a river flow that has a color according to the level of water quality.

\section{Experiments and Analysis}

In this paper there were several experiments that we did including water sampling using Horiba tools, calculation of water quality by storet method, classification of Neural Network, visualization of Surabaya River water quality.

\subsection{Sampling with Horiba Tools}

In this paper water quality sampling used a Horiba measuring instrument. There are 3 sensors that we do calibration before using the Horiba measuring device namely Temperature, $\mathrm{Ph}$, DO. After we do the calibration in accordance with the sensor calibration method in the previous chapter, the tool is ready to be used in taking water. In this paper we take a sample of water quality in the Surabaya River and use 5 water quality parameters, namely Temperature, Ph, DO, Turbidiy and TDS. We take samples in May, September, October. Samples of Surabaya river water quality that we managed to collect amounted to 456 data. From the 456 data that we take, the average parameter values for Temperature and $\mathrm{Ph}$ are not in accordance with the water quality standard, while the DO, Turbidity, and TDS parameter values are in accordance with the water quality standard value..

\subsection{Results of the Storet Method Calculation}

This paper the Storet Method was used to determine river water quality. River water quality is divided into 3, namely the quality of lightly polluted water, medium polluted, heavily polluted. The calculation results with the Storet Method for 456 data that the water quality of the Surabaya River is divided into 3 groups, namely the quality of mild polluted water, moderate pollutants and heavy pollutants. For the calculation method, see table 5 . 
Table 5. Examples of calculation of the value of min, max, and average; then the score of each parameter, and the total score in the Stored method

\begin{tabular}{|c|c|c|c|c|c|c|c|c|}
\hline no & Temperature & PH & Turbidity & DO & TDS & Score & Water Conditions & Point \\
\hline 1 & 29.43 & 9.01 & 50 & 8.17 & 0.084 & & & U12 \\
\hline 6 & 29.47 & 9.95 & 50.3 & 3.69 & 0.087 & & & U12 \\
\hline 12 & 29.86 & 9.49 & 31.4 & 3.5 & 0.089 & & & U12 \\
\hline Min & 29.43 & 9.01 & 50 & 3.69 & 0.084 & & & \\
\hline Max & 29.86 & 9.95 & 50.3 & 8.17 & 0.089 & & & \\
\hline Average & 29.58666667 & 9.483333 & 43.9 & 5.12 & 0.086667 & & & \\
\hline Min Score & -2 & -2 & -2 & 0 & & & & \\
\hline Max Score & -2 & -2 & -2 & & & & & \\
\hline Average Score & -6 & -6 & -6 & & & & & \\
\hline Total & -10 & -10 & -10 & 0 & 0 & -30 & Moderate Pollutant & \\
\hline
\end{tabular}

Table 4 the experiment calculates water quality by the Storet Method, in Table 4 which measures water quality at point $u 12$, at this point the water quality is moderately polluted with a score of -30 . The minimum temperature at the u12 point is 29.43 so that the score can be -2 and the maximum temperature is 29.86 so that the score can be -2 and the average temperature is 29.58 so the score can be -6 so the total score of the temperature is -10 . In the PH parameter that the minimum value is 9.01 so that the score can be -2 and the maximum value is 9.95 so that the score can be -2 and the average value is 9.48 so that the score can be -6 so the total $\mathrm{PH}$ is -10 . In the Turbidity parameter that the minimum value is 50 so the score can be -2 and the maximum value is 50.3 so that the score value can be -2 and the average value is 9.48 so that it can be a score of -6 , so the total value of the Turbidity is -10 . In the DO parameters that the minimum value is 3.69 so that it can score 0 because it is in accordance with the quality standard and the maximum value is 8.17 so that it can score 0 and the average value is 5.12 so that it can score 0 , so the total of the DO value is 0 . In the TDS parameter that the minimum value is 0.084 so that the score can be 0 because it is less than the standard quality and the maximum value is 0.089 so that the score can be 0 and the average value is 0.086 so that it can score 0 , so the total value of the TDS is 0 . After that all the total values of some parameters are added up and the result is -30 so that the water at point $u 12$ is water quality that is moderately polluted

The results of data collection of Surabaya River water quality in May there were $0.11 \%$ of moderate polluted water and $88.88 \%$ of heavily polluted water. Whereas in September there were $23.07 \%$ of lightly polluted water, $24.61 \%$ was moderately polluted and $52.30 \%$ of water was heavily polluted and in October there were $42.45 \%$ of moderate polluted water and $57.54 \%$ of heavily polluted water. So that it can be concluded that in May the river water quality was very poor. 
Of all the data we have succeeded in taking, there are 456 data. Of all the data there were $0.03 \%$ of data whose water quality was classified as lightly polluted, and there were $37.41 \%$ of the data classified as moderately polluted water and there were $59.29 \%$ of the data whose water quality was classified as heavily polluted. From the information above, it can be concluded that the quality of Surabaya River is not good.

\subsection{Classification of Neural Networks}

The data classification in this study uses the Neural Network classification method. In this research, the Neural Network Method is used to apply the rule of the Storet Method using learning data from the Surabaya River water quality sampling using the Horiba tool and using the target data from the calculation of the Surabaya River water quality with the Storet Method, which amounts to 456 data. This target data consists of 3 numbers, namely the numbers 0.1 and 2 . The number 0 is medium polluted, number 1 is heavy pollution while number 2 is mild pollution. For more details, see Table 6.

Table 6. Part of the learning data of the Surabaya River water quality using Horiba tools

\begin{tabular}{|c|c|c|c|c|c|}
\hline Temperature & PH & Turbidity & DO & TDS & $\begin{array}{c}\text { Target } \\
\text { Data }\end{array}$ \\
\hline 29.43 & 9.01 & 75.2 & 8.17 & 0.084 & 0 \\
\hline 29.95 & 9.53 & 68.8 & 3.59 & 0.112 & 1 \\
\hline 29.89 & 9.5 & 43.7 & 2.94 & 0.09 & 0 \\
\hline 30.55 & 6.98 & 23.3 & 3.69 & 0.106 & 0 \\
\hline 30.59 & 6.02 & 20 & 3.28 & 0.106 & 1 \\
\hline 30.55 & 7.73 & 22.9 & 7.47 & 0.106 & 2 \\
\hline 30.52 & 9.06 & 16.6 & 2.89 & 0.106 & 0 \\
\hline 30.63 & 6.12 & 20 & 2.83 & 0.107 & 2 \\
\hline 30.51 & 8.57 & 23.7 & 4.67 & 0.104 & 1 \\
\hline 30.56 & 9.57 & 24.7 & 5.4 & 0.105 & 0 \\
\hline 30.55 & 6.98 & 23.3 & 3.69 & 0.106 & 0 \\
\hline 30.59 & 6.02 & 20 & 3.28 & 0.106 & 0 \\
\hline 30.55 & 7.73 & 22.9 & 7.47 & 0.106 & 0 \\
\hline 30.6 & 9.34 & 20.6 & 8.36 & 0.104 & 0 \\
\hline
\end{tabular}

Surabaya river water quality data as learning data and the results of the calculation of surabaya river water quality with the storet method as a target data amounting to 456 data, we normalize the data using min max normalization and as a classification process we use a neural network classification using miu 0.5 , epoch 10000 and hidden unit 25.20, to test it we use Leave One Out (LOO) so that it gives an accuracy of $70.02 \%$. 
So it can be concluded that the Storet Method rule is applied to the Neural Network using the Surabaya river water quality data as learning data totaling 456 data using Leave One Out (LOO) gives an accuracy of 70.02\%.

\subsection{Visualization of Surabaya River Water Quality}

The visualization In this paper was used to display the results of the classification of Surabaya River water quality in the form of mapping. The river water quality in Surabaya In this paper is symbolized or symbolized by 3 colors, namely green indicating the quality of light polluted water, the yellow color indicates the quality of moderate polluted water and the red color indicates the quality of heavy polluted water. In this paper, we visualized the results of the Surabaya River water quality classification in May, September and October in 2017.

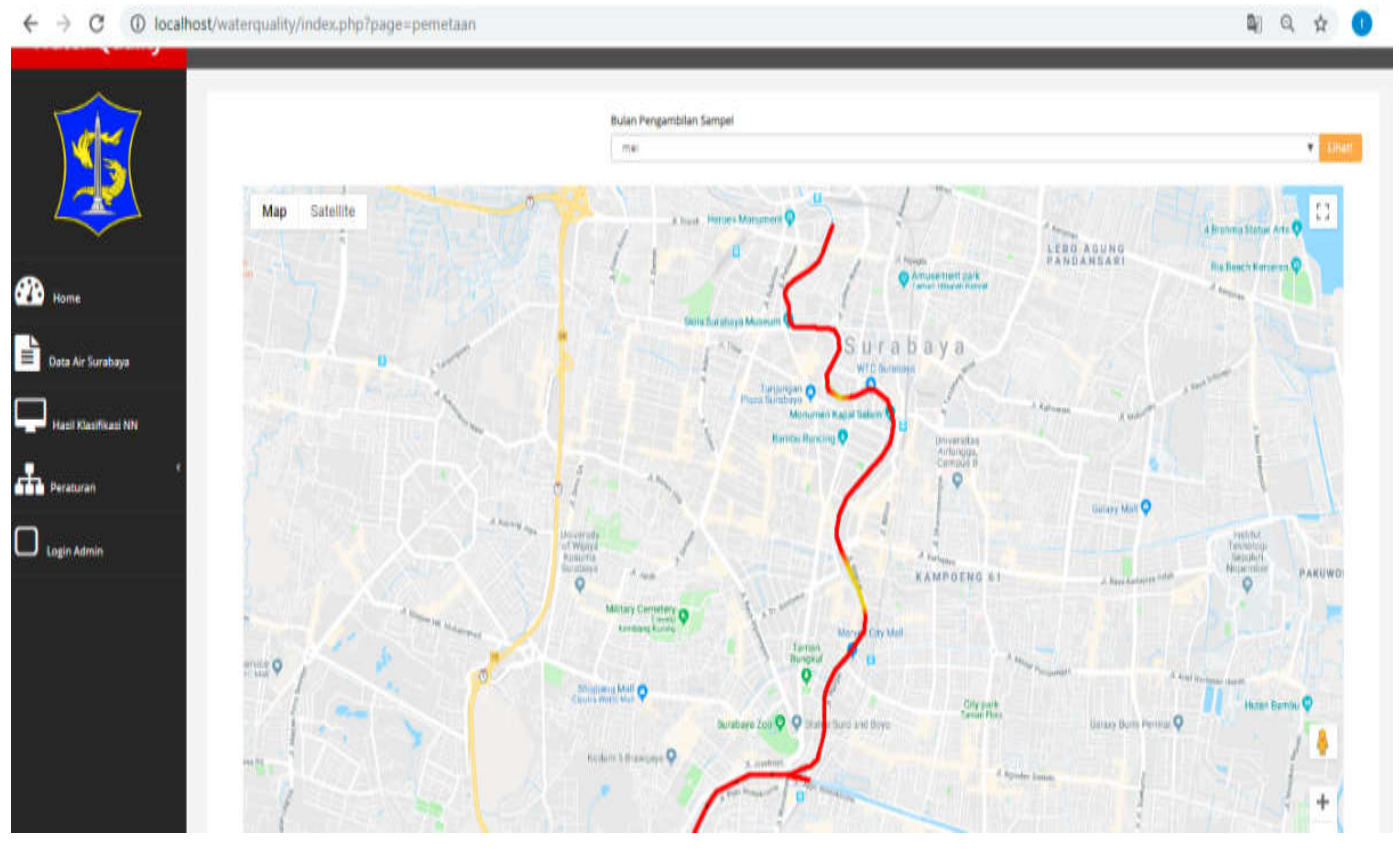

Figure 3. Visualization of Surabaya River Water Quality in May

Figure 3 shows that in May the quality of moderate polluted Surabaya River water quality visualized by yellow streams and heavy pollutants was visualized by a red river flow. In Figure 3 the river flow is dominated by red, indicating that in May the quality of Surabaya River water was heavily polluted. 


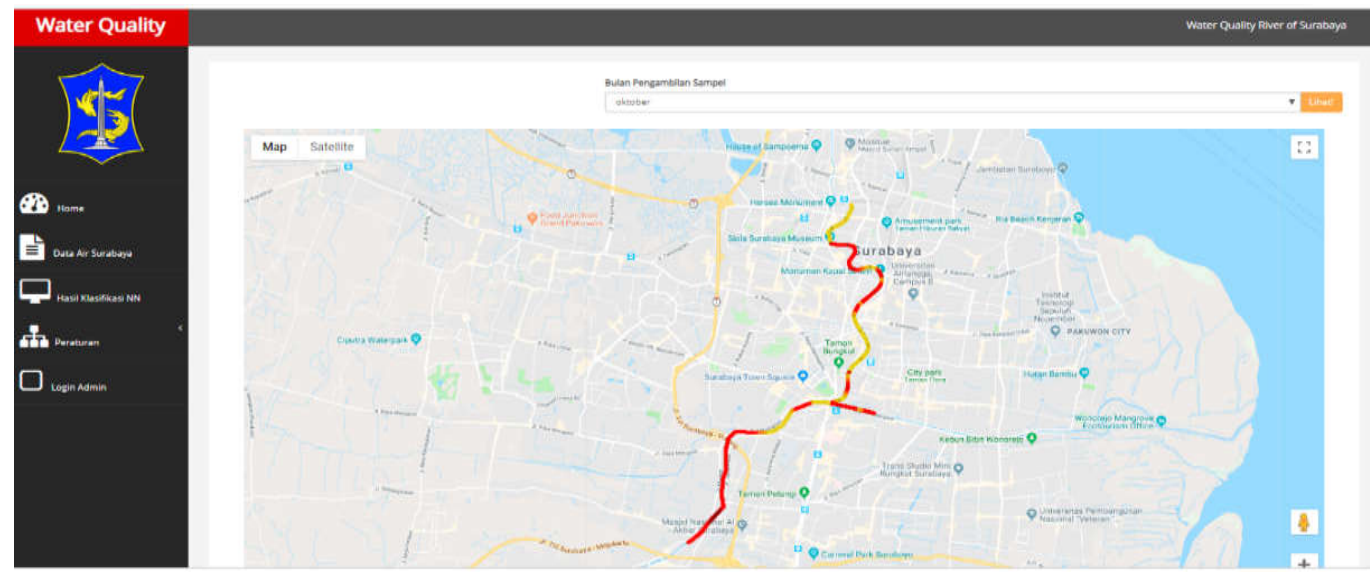

Figure 4. Visualization of Surabaya River Water Quality in October

Figure 4 shows that in October the quality of the moderate polluted Surabaya River water quality visualized by yellow and heavy polluted streams is visualized by a red river flow. In Figure 4 the flow of the river is red and yellow is equally numerous.

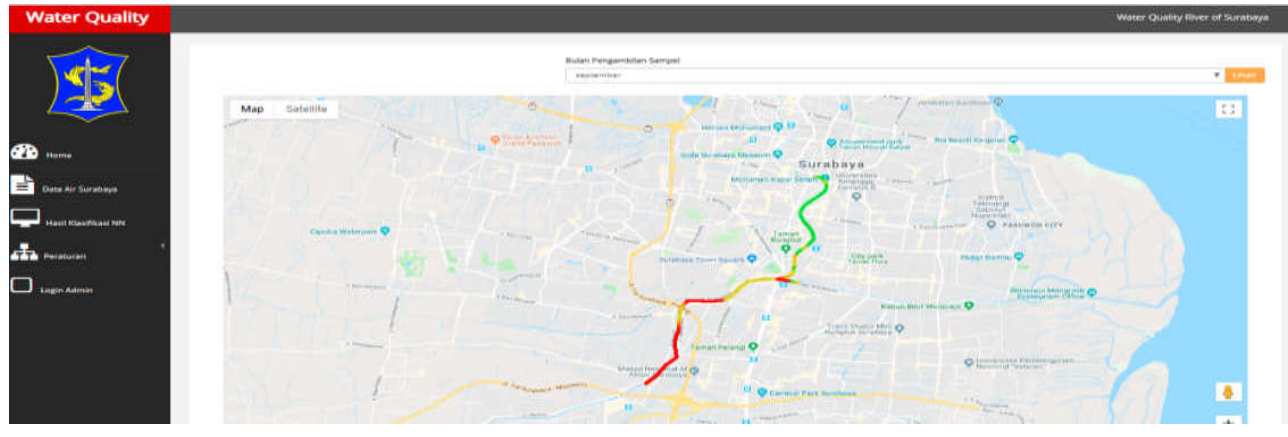

Figure 5. Visualization of Surabaya River Water Quality in September

Figure 5 shows that in September the quality of Surabaya river water is of moderate polluted quality which is visualized by a yellow river flow, heavy pollutants are visualized by a red and polluted river flow visualized by a green stream.

\section{Conclusion}

In this study we took samples of the Surabaya river water quality using the Horiba U52 gauge. We use 5 sensors as parameters including Temperature, Ph, Turbidity, DO, and TDS. We do the sampling in May, September, October. We took a sample of 456 surabaya river water quality data from 64 points in the surabaya river. To determine the quality of Surabaya river water, we use the stored method and we classify it into 3: mildly polluted water, moderate polluted water and heavily polluted water. From all the data that we managed to collect, we amounted to 456 data that 
we classified using the storet method produced $0.03 \%$ of data whose water quality was classified as mildly polluted, and there were $37.41 \%$ of data that was classified as moderately polluted and there were $59.29 \%$ of the data whose water quality classified as heavily polluted. From the above information it can be concluded that the water quality of the Surabaya River is not good.

In this research we use the Neural Network Method to apply the rule of the Storet Method by using learning data from the Surabaya River water quality sampling using the Horiba tool and using target data from the calculation results of the Surabaya River water quality with the Storet Method totaling 456 data. This target data consists of 3 numbers, namely 0 is medium polluted, 1 is heavy polluted while 2 is mild polluted. From the learning data and the target data of Surabaya river water quality, we tested using a miu value of 0.5 , epoch 10000 and a hidden unit of 25.20 and we used Leave One Out (LOO) giving an accuracy of $70.02 \%$. So it can be concluded that the Storet Method rule is applied to the Neural Network using the Surabaya river water quality data as learning data totaling 456 data using Leave One Out (LOO) gives an accuracy of 70.02\%.

\section{Acknowledgements}

Thank you to the people of Surabaya and Surabaya city government for allowing us to take water quality samples at the Surabaya River and thank the PENS campus for lending Horiba sensors to our research

\section{REFERENCE}

[1] Trisnawati Adi and Masduqi Ali, Analysis of Quality and Strategy of Control of Surabaya River Water Pollution. Purification Journal. Vol. 14, No. 2, pp.90-98, 2014.

[2] Arief Muchlisin, Mapping of Suspended Solids Using Landsat Satellite Data, Remote Sensing Journal. Vol. 9 No. 1, pp.67-75, 2012.

[3] Thesa Septine Citri Priyono, Emma Yuliani, Rini Wahyu Sayekti, Study of Determination of Water Quality Status in Surabaya River for the Purpose of Drinking Water Raw Materials, Journal of Water Resources Engineering, Volume 4, Number 1, 2013.

[4] Ihya Ulumuddin, Surabaya River Water Quality is Below the Quality Standards, Sindo Newspaper, accessed on January 30, 2018.

[5] Ayu Ratri Wijayaning Hakim and Yulinah Trihadiningrum, Brantas River Water Quality Study Based on Macroinvertebrates, Journal of the Science and Arts of Pomits, Vol. 1, No. 1, 2012.

[6] Fawaz Al-Badaii, Mohammad Shuhaimi-Othman, and Muhd Barzani Gasim, Water Quality Assessment of the Semenyih River Selangor Malaysia, Hindawi Publishing Corporation Journal of Chemistry Volume 2013.

[7] Sri Rahmawati F, M. Isa Irawan, Nieke Karnaningroem, Pattern of Pollutant Distribution in Surabaya River Using Kohonen Network, 
Proceedings of the Environmental Technology Seminar, ISBN 978-60295595-9-0, 2014.

[8] Muh Faisal Dinniy, Ali Ridho Barakhbah, Entin Martiana Kusumaningtyas, Quality Measurement Classification for Water Treatment using Neural Network with Reinforcement Programming for Weighting Optimization, Knowledge Creation and Intelligent Computing (KCIC), 2016.

[9] MA Huiqun and LIU Ling, Water Quality Assessment using Artificial Neural Network, International Conference on Computer Science and Software Engineering, DOI 10.1109/CSSE.2008.411, IEEE, 2008.

[10] Sofi Defiyanti and Mohamad Jajuli, Integration of Classification and Clustering Methods in Data Mining, National Informatics Conference 2015.

[11] K. Sumathi, S. Kannan,K. Nagarajan, Analysis of student database using Classification Techniques, International Journal of Computer Applications (0975 - 8887), Volume 141 - No.8, May 2016.

[12] Moussa Demba, Algorithm For Relational Database Normalization Up To 3nf, International Journal of Database Management Systems ( IJDMS ) Vol.5, No.3, June 2013.

[13] G.P.Zhang, Neural networks for classification, IEEE Transactions on Systems, Man, and Cybernetics, Part C (Applications and Reviews), Volume: 30 , Issue: 4 , Nov 2000.

[14] Zhenjun Li, A Data Classification Algorithm of Internet of Things Based on Neural Network, iJOE - Vol. 13, No. 9, 2017.

[15] Saravanan K and S. Sasithra, Review on Classification Based on Artificial Neural Networks, International Journal of Ambient Systems and Applications (IJASA) Vol.2, No.4, December 2014.

[16] Stephan Dreiseiti, Lucila Ohno-Mchado, Logistic Regression and Artificial Neural Network Classification Models, Journal of Biomedical Informatics, Volume 35, Issues 5-6, Pages 352-359, October 2002.

[17] Mesterjon, Building Design Implementation Using Google Sketchup 8 Application, Journal of Infotama Media Vol.8 No.2, 2012.

[18] Bayu Rahayudi, Marji, Data Mapping and Water Depth Visualization in Dams or Reservoirs, Journal of Information Technology and Computer Science (JTIIK) p-ISSN: 2355-7699 Vol. 4, No. 2, pp. 111-116, 2017.

[19] Kawa Nazemi, Dirk Burkhardt, Egils Ginters, Jorn Kohlhammer, Semantics Visualization - Definition, Approaches and Challenges, 2015 International Conference on Virtual and Augmented Reality in Education, Procedia Computer Science 75 - 83, 2015.

[20] Dewi Agushinta R, Representing Knowledge Within Human Interaction And Computers, PESAT National Seminar, Gunadanna University, jakarta, ISSN : 18582559, 2005.

[21] Ferihane Kboubi, Anja Habacha Chaibi and Mohamed BenAhmed, 
Semantic Visualization and Navigation Intextual Corpus, International Journal of Information Sciences and Techniques (IJIST) Vol.2, No.1, January 2012.

[22] Kawanazemi, Adaptive semantics Visualization, Springer international publishing switzerland, 2016.

[23] Yanmin Sun, Andrew K. C. Wong and Mohamed S. Kamel, Classification of Imbalanced Data, International Journal of Pattern Recognition and Artificial Intelligence, Vol. 23, No. 04, pp. 687-719 (2009). 